\title{
Purine and pyrimidine metabolism by estuarine bacteria
}

\author{
Gry Mine Berg ${ }^{1, *}$, Niels O. G. Jørgensen ${ }^{2}$ \\ ${ }^{1}$ Department of Geophysics, Stanford University, Stanford, California 94305, USA \\ ${ }^{2}$ Department of Ecology, Royal Veterinary and Agricultural University, Thorvaldsensvej 40, 1871 Frederiksberg, Denmark
}

\begin{abstract}
Nucleotide bases are ubiquitous in living organisms, but the fate of these compounds in natural environments is poorly understood. Here we studied the metabolism of selected purines and pyrimidines in estuarine bacterial assemblages from the Øresund, Denmark. Depletion of nucleotide bases in the incubations was followed by the appearance of urea. The purine guanine and the catabolic intermediates hypoxanthine and xanthine were depleted 2 times faster from seawater incubations than the purine adenine, and 8 to 35 times faster than the pyrimidines thymine, cytosine, and uracil over the course of $141 \mathrm{~h}$. After 48 h, 45 to $60 \%$ of guanine-N, hypoxanthine-N and xanthine-N was converted to urea-N while the conversion of adenine and pyrimidines to urea was slower, corresponding to $34 \%$ and 19 to $23 \%$, respectively. After $96 \mathrm{~h}$, urea concentrations declined in most of the incubations, indicating hydrolysis of urea by the bacterial populations. Bacterial metabolism of adenine in Øresund water was estimated to contribute up to $10 \%$ of the urea pool, but due to the efficient conversion of adenine, the ecosystem importance of adenine degradation to urea production was most likely greater. Growth of bacterial microcolonies on $0.2 \mu \mathrm{m}$ pore-sized polycarbonate filters floating on natural seawater enriched with individual nucleotide bases varied significantly with substrate enrichment. Despite growth of only a small fraction of bacteria present in the natural assemblage on the filters, variation in bacterial microcolony biomass explained most of the variation in substrate utilization and urea production among the treatments. Our results suggest that bacterial catabolism of particularly purines and their intermediates, and to lesser extent pyrimidines, is a major process by which the $\mathrm{N}$ moiety of natural, heterocyclic bases are converted into urea which is easily assimilated.
\end{abstract}

KEY WORDS: Purines · Pyrimidines $\cdot$ Urea production $\cdot$ Estuarine bacteria $\cdot$ Microcolony approach

\section{INTRODUCTION}

Purines and pyrimidines, the nitrogenous bases of nucleotides, are integral components of DNA and RNA. The bases are also constituents of many coenzymes that are involved in energy-carrying reactions, in transfer of organic molecules and in oxidationreduction reactions. In addition, purines are excreted as waste products by a range of terrestrial and marine animals (Nicol 1960, Vogels \& van der Drift 1976). Purines and pyrimidines are nitrogen-rich molecules with 5 and 2 atoms of nitrogen per molecule, respectively (Fig. 1) and can serve both as nitrogen (N) and carbon (C) sources for growth in a variety of microorganisms, including yeast (LaRue \& Spencer 1968), bacteria (DeMoll \& Auffenberg 1993, Schultz et al. 2001), archaea (Stuer-Lauridsen \& Nygaard 1998), protozoa (Hassan \& Coombs 1988) and phytoplankton (Shah \& Syrett 1982, 1984, Antia et al. 1991, Sarcina \& Casselton 1995).

Given their prevalence in organisms, and as excretory products, a high input of purines and pyrimidines to the environment is expected to occur. However, ambient concentrations of purines and pyrimidines in aquatic environments are typically below 0.1 to $10 \mu \mathrm{M}$, suggesting they are cycled quickly (Antia et al. 1991). Microbial purine oxidation involves up to 7 transformation steps before release of the end product urea (Fig. 1). Initially, adenine is deaminated to hypoxanthine, which is subsequently oxidized to xanthine, uric acid, allantoin, and ultimately urea. For each molecule of purine metabolized, 1 molecule of ammonia and 2 
molecules of urea are produced. Similarly, aerobic pyrimidine oxidation results in the production of $1 \mathrm{~mol}-$ ecule of ammonia and 1 molecule of urea per pyrimidine (Vogels \& van der Drift 1976). Therefore, purine and pyrimidine degradation can serve as a major source urea in nature.<smiles>Nc1ncnc2[nH]cnc12</smiles>

Hypoxanthine<smiles>O=c1[nH]cnc2[nH]cnc12</smiles>

Guanine<smiles>CC(C)(C)[C@@H](N)C=O</smiles>

Xanthine

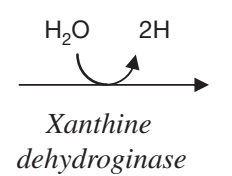

Urea can be an important N source to phytoplankton in coastal environments (Remsen 1971, McCarthy 1972, Kristiansen 1983, Berg et al. 1997). In addition, urea may sustain a significant portion of the $\mathrm{N}$ demand by estuarine bacteria when other $\mathrm{N}$ sources are scarce (Jørgensen 2006, this issue). Whether a significant portion of the urea observed in coastal systems is produced from purine and pyrimidine degradation depends on the prevalence of purine- and pyrimidine-degrading bacteria, and whether these bacteria hydrolyze the urea produced to ammonium. Addition of purines or nucleic acids to anoxic marine sediments (Therkildsen et al. 1996) and to seawater and freshwater bacterial incubations (Berman et al. 1999) leads to an increase in urea concentrations, but the relationship between purine and pyrimidine degradation and urea production has not been examined, nor has the role of purine and pyrimidine hydrolysis versus urea hydrolysis by marine bacterial communities.

We performed a series of purine and pyrimidine additions to incubations of natural estuarine bacteria in order to determine the lability of purines and pyrimidines, and to investigate the potential production and consumption of urea by the bacteria. In order to investigate differences in bacterial biomass with treatment, we used a microcolony epifluorescence technique (Binnerup et al. 1993) where formation of microcolonies on $0.2 \mu \mathrm{m}$ polycarbonate filters, floating on natural seawater enriched with purines and pyrimidines, was quantified. This technique demonstrated good agreement between final gross bacterial biomass and the rate of purine and pyrimidine utilization in natural seawater incubations.

\section{MATERIALS AND METHODS}

Sampling and preparation of bacterial cultures. Water for all experiments was collected between April and August 1998 along the Øresund coast north of Copenhagen, Denmark. Salinity was 12 to 18 ppt and water
Fig. 1. Microbial aerobic purine degradation pathway modified from Vogels \& van der Drift (1976). Molecular structure of the purines adenine and guanine, and the pyrimidines thymine, cytosine and uracil are shown in inserts A and B

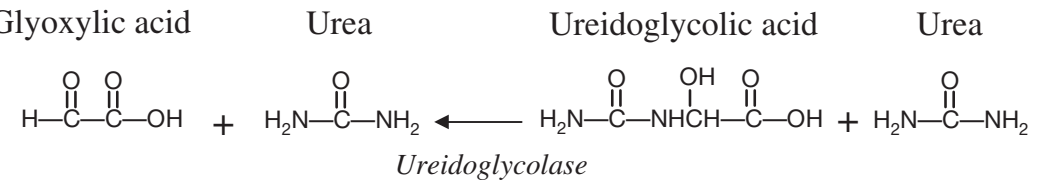


temperature was 10 to $19^{\circ} \mathrm{C}$. For all experiments, particles above bacterial size were removed by filtration through Whatman GF/F filters with an estimated nominal pore size of $0.7 \mu \mathrm{m}$.

Uptake of purines, pyrimidines and purine degradation products. Bacterial uptake of the purines adenine and guanine, their degradation products hypoxanthine and xanthine, and the pyrimidines cytosine, uracil and thymine were tested by the addition of the substrates to duplicate samples of $20 \mathrm{ml} \mathrm{GF/F-filtered}$ water. Final concentrations of nucleotide bases were 2 to $2.5 \mu \mathrm{M}$ ( 4 to $12 \mu \mathrm{g}$-atom $\mathrm{N}^{-1}$ ). The samples were incubated at 15 to $20^{\circ} \mathrm{C}$ for $141 \mathrm{~h}$ in the dark on a shaking table with gentle rotation. At 0, 19, 48, 98 and $141 \mathrm{~h}$, samples for bacterial counts (2 ml) and for HPLC analysis of the concentration of bases $(1 \mathrm{ml}$; filtered through $0.2 \mu \mathrm{m}$ pore size filters and frozen until analysis) were taken. Samples for bacterial abundance were preserved with 0.2- $\mu \mathrm{m}$-filtered and buffered formaldehyde ( $\mathrm{pH} 8.0$; adjusted with borate). The bacterial abundance was determined by acridine orange staining according to Hobbie et al. (1977). Bacteria were counted at 10 different sites on the filters and at each site between 30 and 100 bacteria were counted.

Concentrations of the nucleotide bases were determined by UV absorption at $254 \mathrm{nM}$ after separation by reversed phase HPLC according to the procedure by Waters Corporation. The chromatographic equipment consisted of the following Waters equipment: two 510 pumps, a 717 WISP autoinjector, a 2687 UV/VIS detector and a $4.6 \times 250 \mathrm{~mm}$ Waters Symmetry C-18 column (5 $\mu \mathrm{m}$ particle size). Millenium ${ }^{32}$ software was used for control of the system and for manipulation of the chromatograms. Eluents were $100 \mathrm{mM}$ ammonium acetate adjusted to $\mathrm{pH} 6.0$ with (A) acetic acid and (B) methanol. Column temperature was $30^{\circ} \mathrm{C}$ and the

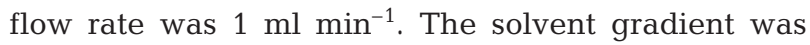
according to Table 1 . The detection limit of the bases varied from 50 to $100 \mathrm{nM}$ depending on the elution time (the fastest eluting peaks had the lowest detection limit). The sample injection volume was $100 \mu \mathrm{l}$.

To investigate the production of urea from adenine at naturally occurring adenine concentrations, in situ adenine concentrations were measured by HPLC as above with the following modifications to improve detection: adenine in Øresund water was pre-concentrated using extraction cartridges made of C-18 material (Waters Oasis HLB Plus). The cartridges were conditioned with $5 \mathrm{ml}$ Milli-Q water after which $40 \mathrm{ml}$ sample was slowly loaded onto the cartridge with a peristaltic pump $\left(1 \mathrm{ml} \mathrm{min}{ }^{-1}\right)$. A trace amount of $\left[{ }^{14} \mathrm{C}\right]-$ adenine was added to the $40 \mathrm{ml}$ water sample and was used to determine recovery of adenine on the cartridge. The cartridges were washed with $10 \mathrm{ml}$ Milli-Q water after which the content was slowly eluted with
Table 1. Solvent gradient used for determination of nucleotide base concentrations. $\mathrm{A}=100 \mathrm{mM}$ ammonium acetate, $\mathrm{B}=$ methanol. Gradient curves: $0=$ no change, $6=$ linear change, $11=$ immediate change

\begin{tabular}{|lrcc|}
\hline Time (min) & $\% \mathrm{~A}$ & $\% \mathrm{~B}$ & Curve \\
\hline 0 & 100 & 0 & 0 \\
9.5 & 96 & 4 & 6 \\
13.5 & 96 & 4 & 6 \\
19.0 & 85 & 15 & 6 \\
26.5 & 85 & 15 & 6 \\
27.0 & 50 & 50 & 6 \\
30.5 & 100 & 0 & 11 \\
46.0 & 100 & 0 & 11 \\
& & & \\
\hline
\end{tabular}

acetonitrile according to the recommendations of the manufacturer, and collected. After the acetonitrile was evaporated, the samples were dissolved in $500 \mu \mathrm{l}$ Milli-Q water. Subsamples were analyzed by HPLC as above or were radioassayed. The average recovery of $\left[{ }^{14} \mathrm{C}\right]$-adenine was determined to be $11 \%$ (range 10 to $13 \%$; results not shown). The relatively low recovery of adenine most likely indicates that other organic molecules also absorbed to the C-18 material. The measured recovery was used for calculation of in situ adenine concentrations.

Dissolved nitrogen determinations. Changes in concentrations of urea, nitrate $\left(\mathrm{NO}_{3}{ }^{-}\right)$and ammonium $\left(\mathrm{NH}_{4}{ }^{+}\right)$were also determined in the incubations with additions of nucleotides. Urea concentration was determined by the monoxime method according to Price \& Harrison (1987). Concentrations of $\mathrm{NO}_{3}{ }^{-}$and $\mathrm{NH}_{4}{ }^{+}$were determined by standard autoanalyzer technique.

Bacterial adenine metabolism: uptake, respiration and conversion into urea. Bacterial utilization of adenine and its conversion to urea was investigated under ambient adenine concentration by trace addition of $\left[{ }^{14} \mathrm{C}\right]$-adenine to $20 \mathrm{ml} \mathrm{GF} / \mathrm{F}$-filtered water samples. Each bottle received $0.045 \mu \mathrm{Ci}\left[\mathrm{U}_{-}{ }^{14} \mathrm{C}\right.$ ]-adenine (specific activity of $287 \mathrm{mCi} \mathrm{mmol}{ }^{-1}$, Amersham Biosciences), corresponding to a final concentration of $7.95 \mathrm{nM}$ adenine. At 3, 24, 48, 96 and $168 \mathrm{~h}$, (1) incorporation of adenine into bacterial biomass (collection of bacteria on $0.2 \mu \mathrm{m}$ filters), (2) respiration of adenine (collection of $\left[{ }^{14} \mathrm{C}\right]-\mathrm{CO}_{2}$ ), and (3) conversion of adenine into urea (urease mediated hydrolysis of $\left[{ }^{14} \mathrm{C}\right]$-urea to $\left[{ }^{14} \mathrm{C}\right]-\mathrm{CO}_{2}$ ) were determined in triplicate. Details of the different procedures follow below.

(1) Incorporation of adenine was determined at each sampling time by addition of formaldehyde to a final concentration of $2 \%$ to stop biological activity. The water was subsequently filtered through $0.2 \mu \mathrm{m}$ membrane filters and the filters were radioassayed. 
(2) Respiration of adenine was determined by mounting rubber membranes with $\mathrm{CO}_{2}$ traps $(1 \mathrm{ml}$ Eppendorf-type vial with an accordion-folded wick attached to the membrane with a $0.5 \mathrm{~mm} 20$ fishing nylon line) on the bottles. At each sampling time, 3 replicate bottles received $500 \mu 10 \% \mathrm{H}_{3} \mathrm{PO}_{4}$ to release $\left[{ }^{14} \mathrm{C}\right]-\mathrm{CO}_{2}$. The wicks in the $\mathrm{CO}_{2}$ traps were wetted with $100 \mu \mathrm{l}$ phenylethylamine with a hypodermic needle and incubated for $1 \mathrm{~h}$ on a shaking table to adsorb the $\mathrm{CO}_{2}$ produced. The traps were subsequently transferred to scintillation vials and radioassayed after addition of scintillation cocktail. Linearity of the $\left[{ }^{14} \mathrm{C}\right]-\mathrm{CO}_{2}$ production from degradation of $\left[{ }^{14} \mathrm{C}\right]$-adenine over time was tested in preliminary studies. The linearity experiments demonstrated that there was a linear development in $\left[{ }^{14} \mathrm{C}\right]-\mathrm{CO}_{2}$ production in samples collected $0.5,1,2,3$ and $4 \mathrm{~h}$ after $\left[{ }^{14} \mathrm{C}\right]$-adenine addition, indicating that adenine taken up by the bacteria was immediately metabolized (results not shown).

(3) Conversion of adenine to urea was determined at each sampling time by addition of $50 \mu$ concentrated $\mathrm{HCl}$ to stop biological activity and to release $\left[{ }^{14} \mathrm{C}\right]-\mathrm{CO}_{2}$. Preliminary tests demonstrated that a small percentage of $\left[{ }^{14} \mathrm{C}\right]-\mathrm{CO}_{2}$ from respiration of ${ }^{14} \mathrm{C}$-adenine remained in the samples after acidification. Since all $\left[{ }^{14} \mathrm{C}\right]-\mathrm{CO}_{2}$ in the samples in the following urease treatment would be assumed to originate from $\left[{ }^{14} \mathrm{C}\right]$-urea, traces of $\left[{ }^{14} \mathrm{C}\right]-\mathrm{CO}_{2}$ were removed from the samples by freeze-drying. The samples were re-dissolved in the serum bottles in $20 \mathrm{ml} 10 \mathrm{mM}$ potassium phosphate buffer with $10 \mathrm{mM}$ lithium chloride and $1 \mathrm{mM}$ EDTA ( $\mathrm{pH}$ 8.2) prior to addition of 10 units of urease enzyme. This buffer was recommended by Sigma-Aldrich to optimize the enzyme reaction. The serum bottles were closed with membranes with attached $\mathrm{CO}_{2}$ traps. During a $2.5 \mathrm{~h}$ incubation period, urease hydrolyzed $\left[{ }^{14} \mathrm{C}\right]-$ labelled and unlabelled urea to $\left[{ }^{14} \mathrm{C}\right]-\mathrm{CO}_{2}$ and $\mathrm{CO}_{2}$ (and $\mathrm{NH}_{4}{ }^{+}$). Finally, $1.5 \mathrm{ml} \mathrm{H}_{3} \mathrm{PO}_{4}$ was added to each sample and the wicks were wetted with $100 \mu \mathrm{l}$ phenylethylamine to absorb the $\mathrm{CO}_{2}$ produced. In situ urea concentrations were determined as described above.

The efficiency of the applied $\mathrm{CO}_{2}$ traps for collection of $\left[{ }^{14} \mathrm{C}\right]-\mathrm{CO}_{2}$ from $\left[{ }^{14} \mathrm{C}\right]$-urea after treatment with urease was tested for different urea concentrations. Water samples of $20 \mathrm{ml}$ received combinations of unlabelled urea at 0.5 to $4.0 \mu \mathrm{M}$ urea and $\left[{ }^{14} \mathrm{C}\right]$-urea at concentrations of 0.01 to $0.5 \mu \mathrm{Ci}$ per sample (specific activity was $56 \mathrm{mCi} \mathrm{mmol}^{-1}$; Perkin Elmer). The recovery of $\left[{ }^{14} \mathrm{C}\right]-$ $\mathrm{CO}_{2}$ varied from 19 to $24 \%$ (mean of $22 \%$; results not shown). When tested with $\left[\mathrm{H}_{2}{ }^{14} \mathrm{CO}_{3}\right]$ (ampoules for $\left[{ }^{14} \mathrm{C}\right]$ primary measurements), the phenylethylamine traps had a recovery of $97 \%\left[{ }^{14} \mathrm{C}\right]-\mathrm{CO}_{2}$ after acidification (results not shown). Since we were unable to determine the reason for the low recovery in $\left[{ }^{14} \mathrm{C}\right]-\mathrm{CO}_{2}$ from urea, we assumed a $22 \%$ recovery when calculating the total urea production from adenine.

Bacterial growth on purines and pyrimidines investigated through a microcolony approach. Uptake of purines, their degradation products and pyrimidines was also investigated through a microcolony technique according to Binnerup et al. (1993). The principle of this technique is that bacteria are filtered onto polycarbonate filters that float on top of a medium enriched with the substrate of interest. Only bacteria capable of utilizing the substrate(s) in the medium will divide and form new cells. In addition to selection for substrate utilization, the technique also separates bacterial growth from protozoan grazing if natural water and soil samples are studied. At the end of the incubation, the number of colonies, the number of bacteria within the colonies, and the size of the bacteria can be enumerated. The bacterial biomass is expected to represent the quality of the substrate to the bacteria.

In the present investigation, $500 \mu \mathrm{l} \mathrm{GF/F-filtered}$ Øresund water (ca. $2 \times 10^{5}$ bacterial cells) was filtered onto $0.2 \mu \mathrm{m}$ pore size and $25 \mathrm{~mm}$ diameter Nuclepore polycarbonate filters and transferred to $9 \mathrm{~cm}$ plastic Petri dishes with $50 \mathrm{ml}$ of $0.2 \mu \mathrm{m}$ filtered Øresund water. Each dish was enriched with $2.5 \mu \mathrm{M}$ of one purine, degradation product, pyrimidine or urea as in the initial incubation experiment. After $7 \mathrm{~d}$, the filters were gently blotted, transferred to a solution of $0.015 \%$ acridine orange in a $2.5 \mathrm{~cm}$ Petri dish, and allowed to float for $5 \mathrm{~min}$. After $5 \mathrm{~min}$, filters were transferred 2 additional times to dishes with Milli-Q water to rinse out excess acridine orange. The filters were inspected by epifluorescence technique (Zeiss Axioplan microscope) using low magnification to identify presence and numbers of microcolonies on the filters. Individual colonies were recorded by a Quantix KAF 1400-G2 CCD camera (Photometrics) at $100 \times$ magnification (Fig. 2A). All microcolonies on each filter were recorded. Number and area of individual bacteria in the microcolonies were subsequently determined using the Image-Pro Plus software (v. 4.5; Media Cybernetics). In some instances bacteria in the microcolonies were embedded in an organic matrix that was slightly stained with acridine orange (Fig. 2B). Since this stained, organic matrix interfered with the digital registration of number and size of the bacteria, the matrix was removed with Image-Pro Plus. With the software a background image without bacteria was produced by erosion $(11 \times 11$ pixels, 3 passes $)$ and dilation $(11 \times 11$ pixels, 3 passes $)$ of the original image. The background image was subtracted from the original image, leaving only the bacteria in the image, as can be seen in Fig. 2C. Subsequently, the number of bacteria in the microcolonies was quantified using ImagePro Plus. 


\section{RESULTS}

\section{Uptake of purines, pyrimidines and production of urea}

Purines and their intermediates were taken up faster than pyrimidines over the course of $141 \mathrm{~h}$ (Fig. 3A). Guanine and the intermediates hypoxanthine and xan-

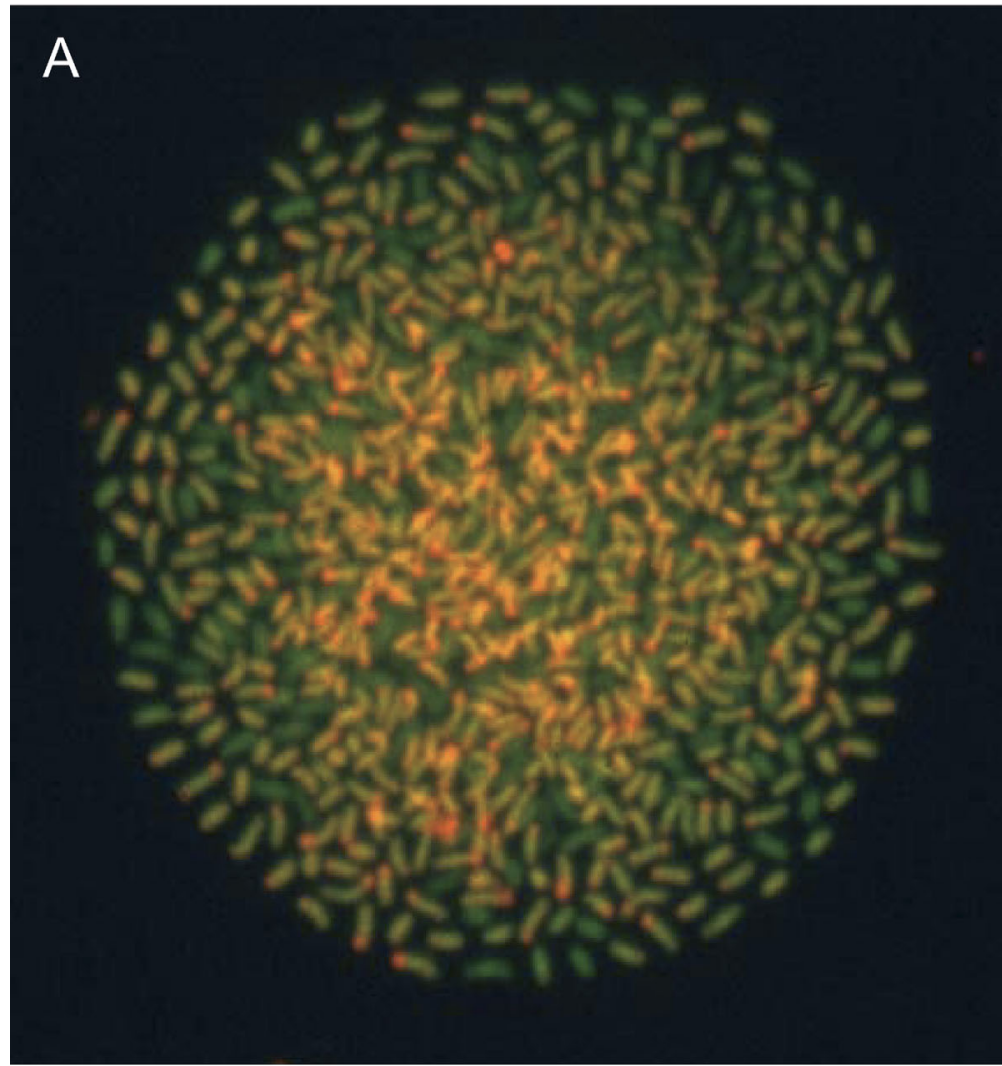

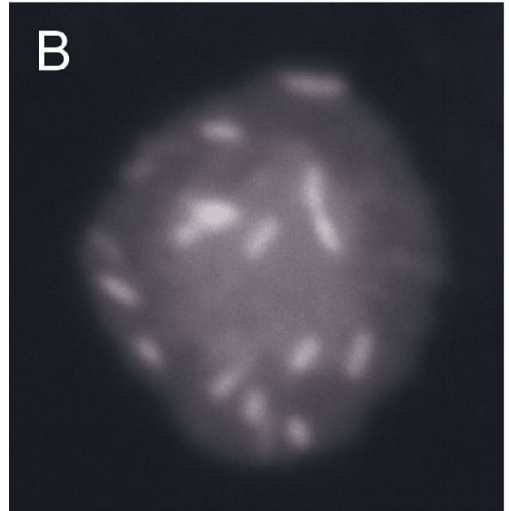

Original picture

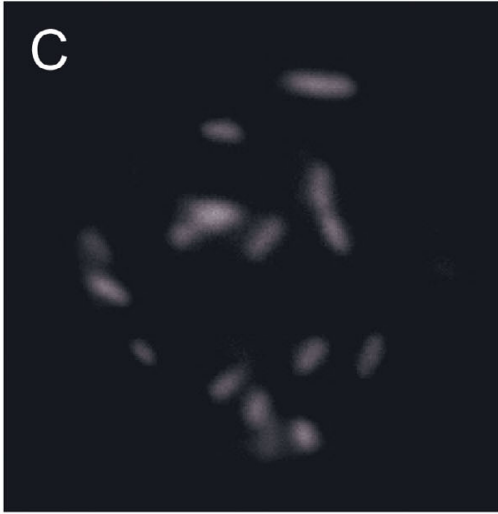

After optimization
Fig. 2. (A) Example of an acridine orange stained microcolony recorded at $100 \times$ magnification. (B) Example of bacterial cells embedded in an organic matrix in the microcolony. (C) Image manipulation with Image-Pro Plus software to remove the organic matrix background from the bacterial cells in (B). The background image was subtracted from the original image, leaving only the bacteria in the image thine were depleted from the medium within the first $48 \mathrm{~h}$ of the experiment, whereas adenine was depleted within $96 \mathrm{~h}$. Uracil appeared to be the most bioavailable pyrimidine and was depleted from the medium after $141 \mathrm{~h}$. Thymine and cytosine concentrations decreased 26 and $46 \%$, respectively, over the course of the experiment (Fig. 3A). Concomitant with changes in purine concentrations, changes in concentrations of $\mathrm{NH}_{4}{ }^{+}$and $\mathrm{NO}_{3}{ }^{-}$were monitored (data not shown). During the initial $48 \mathrm{~h}, \mathrm{NH}_{4}{ }^{+}$ declined from $9 \pm 1$ to $3 \pm 2 \mu \mathrm{M}$ and remained at that level during the rest of the incubation. Initial and final concentrations of $\mathrm{NO}_{3}{ }^{-}$were similar, $28 \pm 2$ and $31 \pm 2 \mu \mathrm{M}$, respectively (mean concentrations $\pm 1 \mathrm{SD}$ ). The additions of purines and pyrimidines most likely exceeded natural concentrations in Øresund water several-fold, as the concentration of adenine varied between 0.015 and $0.053 \mu \mathrm{M}$ in April when the water was collected.

Consistent with the pattern in purine utilization, more urea was produced in the incubations with guanine, xanthine and hypoxanthine compared with the other incubations (Fig. 3B). In the first $48 \mathrm{~h}$ of the time course, urea production corresponded to 60,46 and $45 \%$ of xanthine, hypoxanthine and guanine additions, respectively (based on $N$ content in the bases and in urea) (Fig. 3A,B). In contrast, urea production equalled 19 to $23 \%$ of the pyrimidine additions in the same period. The urea concentration in the adenine treatment corresponded to $34 \%$ of the adenine addition, intermediate between that in the treatments with the other purines and pyrimidines. It was assumed that 2 urea molecules were produced for each purine molecule, and that 1 urea molecule was produced for each pyrimidine molecule, when calculating the efficiency of purine or pyrimidine conversion to urea (Fig. 1). After 48 h, urea concentrations decreased or increased at a slower rate in 3 of the purine incubations (guanine, hypoxanthine and adenine) suggesting that urea was consumed simultaneously with its production (Fig. 3B). The highest urea concentrations of 5.2 and $4.0 \mu \mathrm{M}$ occurred at $96 \mathrm{~h}$ in the xanthine and guanine incubations, respectively, and corresponded to $84 \%$ (xanthine) and $80 \%$ (guanine) of the purine additions. In a parallel incubation 
with untreated Øresund water, the urea concentration was $0.35 \pm 0.15 \mu \mathrm{M}$ and no increase or decrease in concentration was observed (data not shown).

The addition of purines, pyrimidines and urea stimulated bacterial growth relative to the control, which
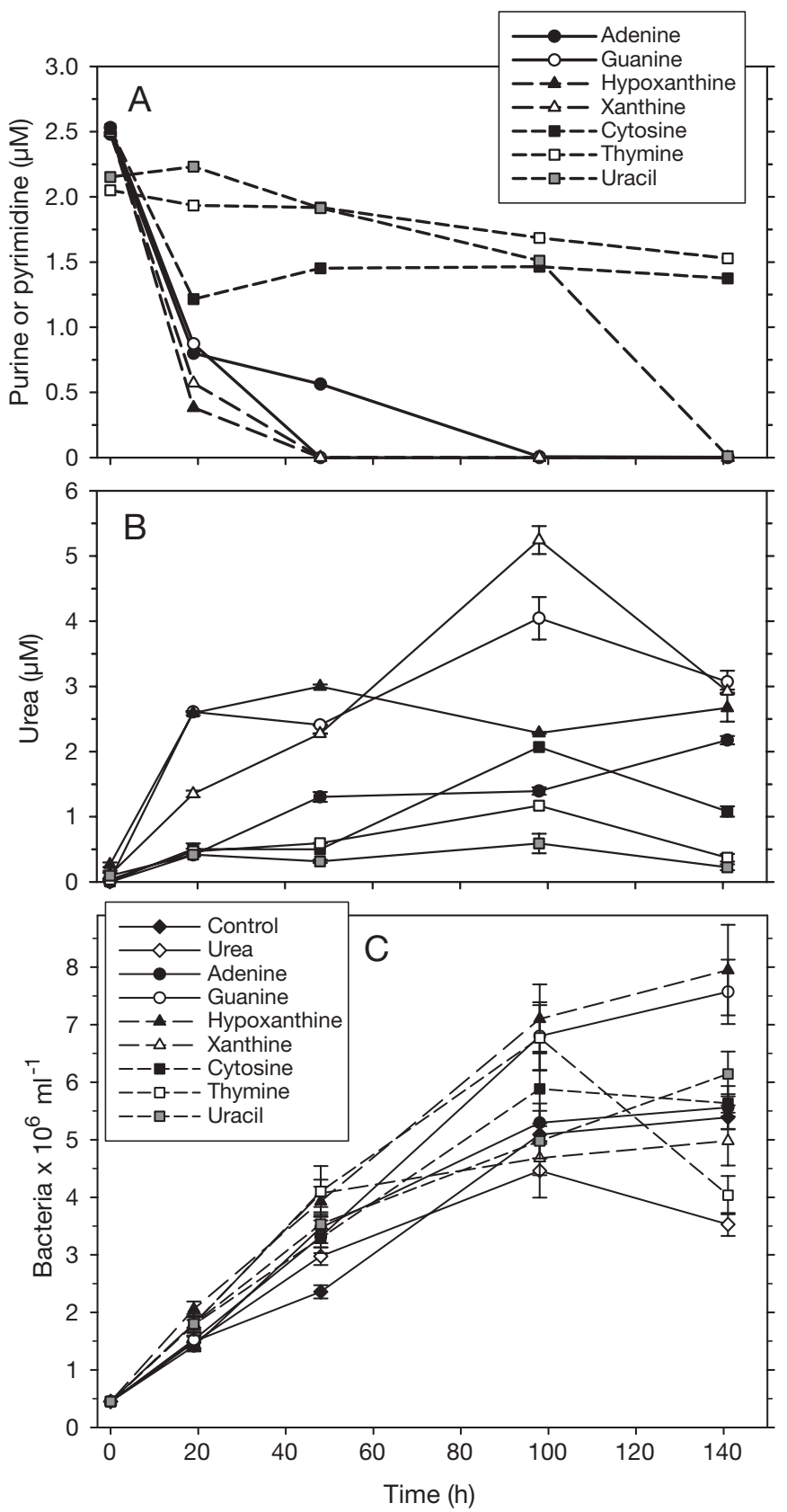

Fig. 3. (A) Depletion of adenine, guanine, hypoxanthine, xanthine, urea, cytosine, thymine, and uracil in cultures of Øresund water, filtered through Whatman GF/F-filters $(0.7 \mu \mathrm{m}$ pore size). The cultures were spiked with free bases to final concentrations of ca. $2.5 \mu \mathrm{M}$. GF/F-filtered Øresund water without additions served as a control. (B) Production of urea in the cultures. (C) Acridine orange direct counts of bacteria in the cultures as described above. Error bars indicate deviation from the mean $(n=2)$ was filtered seawater without nutrient addition. The urea treatment supported less bacterial growth than the purine and pyrimidine treatments (Fig. 3C). By $48 \mathrm{~h}$, bacterial abundance in all the treatments was on average $52 \pm 17 \%$ higher than in the control. By $96 \mathrm{~h}$, the xanthine and urea treatments had $10 \pm 3 \%$ lower bacterial densities than the control, and thymine, hypoxanthine and guanine treatments had $35 \pm 3 \%$ higher densities compared to the control (Fig. 3C). By $141 \mathrm{~h}$, there were no further increases in bacterial abundance in the different treatments. At this point, we observed the presence of nanoflagellates in some treatments. Their densities were not quantified but could have been a factor in the increased variability among the treatments leading up to $141 \mathrm{~h}$.

\section{Bacterial adenine incorporation and conversion to urea}

The $\left[{ }^{14} \mathrm{C}\right]$-adenine incubations were made to obtain conservative estimates of the in situ rates of urea production due to bacterial decomposition of purines. Adenine was chosen because we could not detect concentrations of other purines or pyrimidines with the present HPLC method. $\left[{ }^{14} \mathrm{C}\right]$-labeled adenine was added at trace level to incubations with GF/F filtered seawater (nominal pore size $0.7 \mu \mathrm{m}$ ) and followed for $169 \mathrm{~h}$. In the first $49 \mathrm{~h}$, approximately $50 \%$ of the added $\left[{ }^{14} \mathrm{C}\right]$-adenine isotope was recovered in the bacterial biomass and only a fraction $(<5 \%)$ of $\left[{ }^{14} \mathrm{C}\right]$ was incorporated into urea (Fig. 4). By $96 \mathrm{~h}$, the proportion of $\left[{ }^{14} \mathrm{C}\right]$ in the bacteria had declined to $29 \%$, while $34 \%$ of the $\left[{ }^{14} \mathrm{C}\right]$ was recovered in urea. From 96 to $169 \mathrm{~h}$, the incorporation of $\left[{ }^{14} \mathrm{C}\right]$ slightly increased while the proportion of $\left[{ }^{14} \mathrm{C}\right]$ in urea declined to $14 \%$. Respiration of adenine increased throughout the time course with $50 \%$ of the added adenine having been respired by $169 \mathrm{~h}$. Recovery of the added $\left[{ }^{14} \mathrm{C}\right]$-adenine isotope in bacterial biomass, $\mathrm{CO}_{2}$ and urea was $75 \%$ at 25 and $49 \mathrm{~h}$, and increased to 97 and $104 \%$ at 96 and $169 \mathrm{~h}$, respectively. The conversion efficiency of adenine- $\mathrm{C}$ to urea-C in this experiment was $34 \%$, corresponding to a conversion efficiency of adenine- $\mathrm{N}$ to urea- $\mathrm{N}$ of $68 \%$ ( 2 urea molecules are produced from each adenine molecule). In a similar, preliminary experiment, $28 \%$ of the added $\left[{ }^{14} \mathrm{C}\right]$-adenine- $\mathrm{N}$ was converted to urea- $\mathrm{N}$ (data not shown). This was comparable to the $\mathrm{N}$ conversion efficiency of $34 \%$ in the purine uptake experiment (Fig. 3A,B). Relative to the ambient urea and adenine concentrations of about $350 \mathrm{nM}$ and 15 to $53 \mathrm{nM}$, respectively, in Øresund water, this means that 3 to $10 \%$ of the urea pool in the water might have originated from adenine alone. 


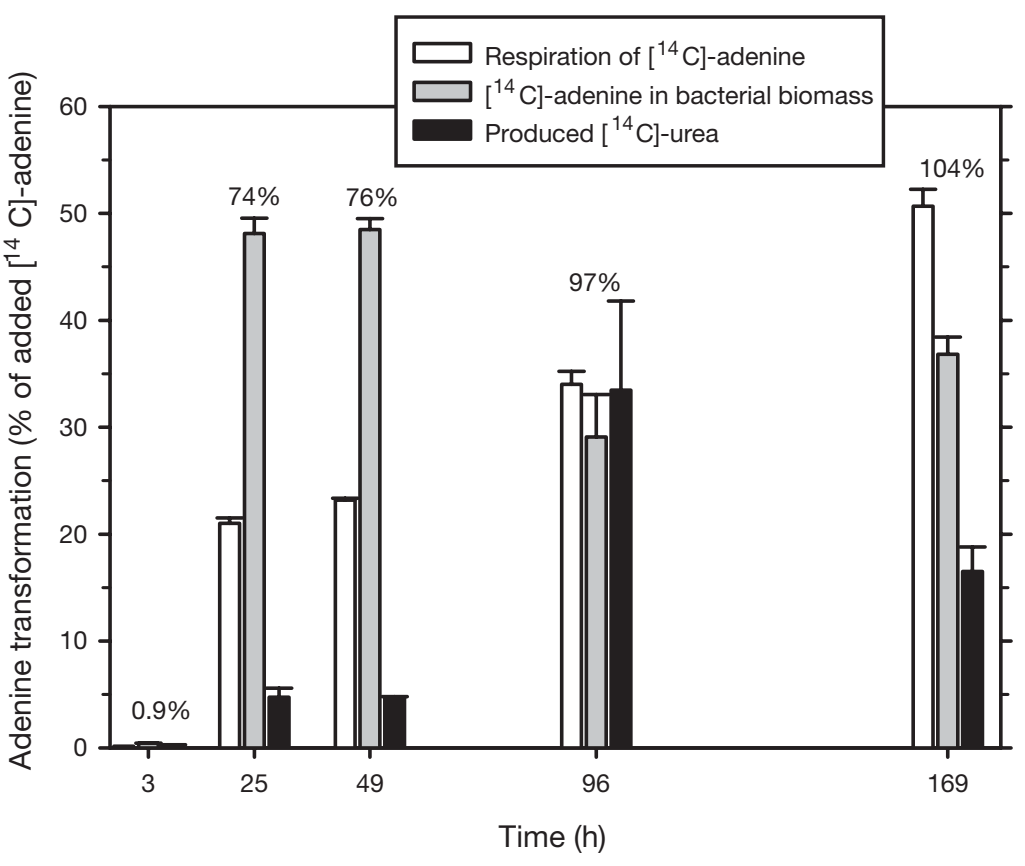

Fig. 4. Transformation of $\left[{ }^{14} \mathrm{C}\right]$-adenine added at trace level to Whatman $\mathrm{GF} / \mathrm{F}$ filtered seawater, as percent of the added adenine, into $\left[{ }^{14} \mathrm{C}\right]$-urea, bacterial biomass and $\left[{ }^{14} \mathrm{C}\right]-\mathrm{CO}_{2}$. Recovery of the added $\left[{ }^{14} \mathrm{C}\right]$ isotope in urea, biomass and $\mathrm{CO}_{2}$ is indicated over the columns. Mean $\pm 1 \mathrm{SD}$ $(\mathrm{n}=3)$ shown and in the control, the bacterial size was 120 to 140 pixels (difference in size among these treatments not significant; $t$-test, $\mathrm{p}>0.05)$. In contrast, the bacteria in the adenine treatment were $26 \%$ larger in size relative to the control (significantly different from the control and cytosine; $t$-test, $\mathrm{p}<0.05)$. The difference in size suggested that bacteria metabolizing adenine tended to produce larger cells, whereas bacteria metabolizing guanine and the purine intermediates divided faster and therefore produced smaller cells. As a result, total bacterial biomass (bacterial area $\times$ bacterial abundance) demonstrated that growth on adenine was intermediate between the control-urea-pyrimidines group and the guanine-xanthine-hypoxanthine group (Fig. 5D).

Microcolony bacterial biomass agreed well with the uptake of purines and pyrimidines (Fig. 3A) and with the production of urea (Fig. 3B) measured independently (Fig. 6A,B). Bacterial biomass was slightly better correlated with purine and pyrimidine uptake $\left(\mathrm{r}^{2}=0.92\right)$ than with urea production $\left(r^{2}=0.87\right)$.

\section{Microcolony growth}

The number of bacterial microcolonies on each of the polycarbonate filters was $53 \pm 5$ in the control, adenine and guanine treatments (Fig. 5A). In the hypoxanthine and xanthine treatments, 25 and $52 \%$ more colonies were found than in the control. In contrast, the number of microcolonies in the uracil, urea, cytosine and thymine treatments was 34 to $71 \%$ lower than in the control.

A more pronounced difference among the treatments was evident in the total number of bacteria (i.e. sum of bacteria in colonies). Here, the number increased 420 , 480 and $540 \%$ in the hypoxanthine, guanine, and xanthine treatments, respectively, relative to the control (Fig. 5B). In contrast, the urea, adenine and the pyrimidine treatments demonstrated no difference in total bacterial number relative to the control. It appeared that hypoxanthine, guanine, and xanthine sustained a higher growth rate than the other substrates and the control, which also influenced the size of the bacteria in the microcolonies. The bacteria in the fast-growing microcolonies (hypoxanthine, guanine, and xanthine) were on average $32 \pm 5 \%$ smaller in size relative to the bacteria in the control (Fig. 5C). The bacteria in the fast-growing colonies were similar in size $(t$-test, $\mathrm{p}>$ 0.05). In the cytosine, thymine and uracil enrichments,

\section{DISCUSSION}

Although purine and pyrimidine bases are ubiquitous components of all living material, almost no quantitative data exist on concentrations and fate of the bases in marine environments. Similarly, the significance of purines and pyrimidines to the production of urea in natural environments has received little attention in the literature, even though urea is an important $\mathrm{N}$ source to phytoplankton compared with inorganic nitrogen such as $\mathrm{NH}_{4}{ }^{+}$and $\mathrm{NO}_{3}{ }^{-}$(McCarthy 1972, Berman \& Bronk 2003). Our results suggest significant differences in the lability of purines and pyrimidines to marine bacterial populations, and we further demonstrate a direct link between purine and pyrimidine decomposition and urea production.

\section{Degradation of purines}

Assuming that the rates of purine and pyrimidine uptake measured in the present investigation approximate the true potential of natural marine bacterial populations, guanine is taken up 8 to 35 times faster than the pyrimidines thymine, cytosine and uracil, and twice as fast as adenine. The reason for adenine being metabolized significantly slower compared to guanine 

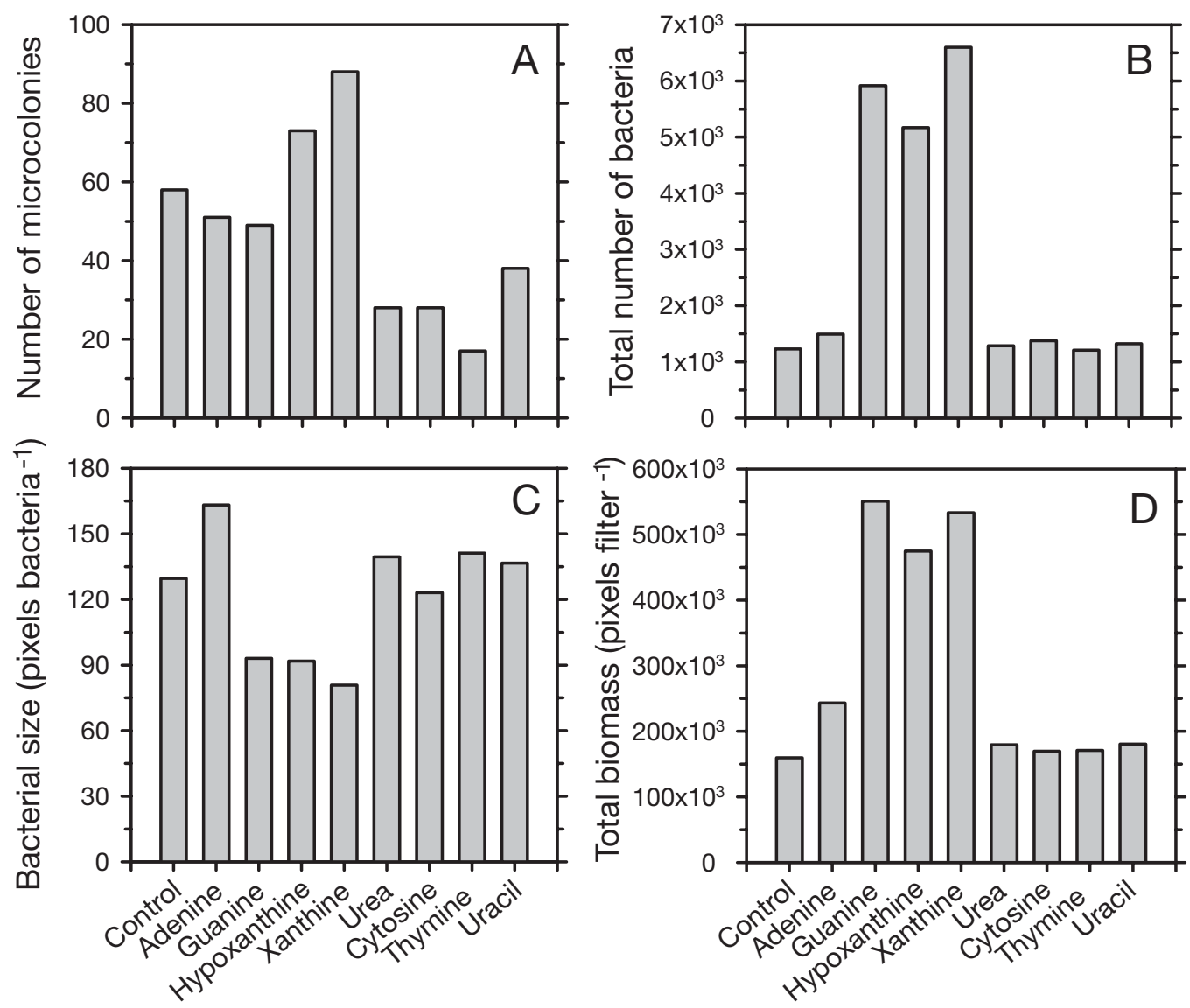

Fig. 5. Growth of microcolonies on polycarbonate filters floating on top of $0.2 \mu \mathrm{m}$ filtered Øresund seawater spiked with $2.5 \mu \mathrm{M}$ adenine, guanine, hypoxanthine, xanthine, urea, cytosine, thymine, uracil and a control with no addition. (A) Number of microcolonies per $25 \mathrm{~mm}$ filter. (B) Total number of bacteria in microcolonies per filter. (C) Size of bacterial cells (bacterial area in terms of recorded numbers of pixels per bacteria). (D) Total bacterial biomass (bacterial area $\times$ bacterial abundance) per filter

by marine bacterial populations is intriguing and unclear. Both purines contain 5 atoms of nitrogen and can be deaminated to the intermediates hypoxanthine and xanthine via adenine deaminase and guanine deaminase, respectively (Fig. 1).

Many bacteria can degrade adenine, but some eubacteria, among these actinomycetes, lack adenine deaminase and have a low or no degradation of adenine (Watanabe \& Ohe 1972, Vitols et al. 1974, Vogels \& van der Drift 1976). Microorganisms without adenine deaminase may produce hypoxanthine from adenine by synthesizing adenosine which is converted to inosine and hypoxanthine (LeChevalier et al. 1982). In other microorganisms, adenine can inhibit purine utilization in general (Eschmann \& Kaltwasser 1980). These metabolic differences may be related to the availability of the different purines in the habitat of the microorganism. For example, guanine and hypoxanthine are produced as excretion products by a marine ciliate (Soldo et al. 1978) and guanine is a major component of fish skin and scales (Nicol 1960, Staley \&
Ewing 1992). The prevalence of guanine and hypoxanthine excretion by ciliates and other zooplankton in marine environments is not known, but the high lability of guanine and hypoxanthine to marine bacteria may well reflect its rate of production by higher trophic levels and its availability in the water column. Consistent with this, investigations of purine utilization by marine phytoplankton demonstrate that guanine and hypoxanthine are preferentially assimilated to adenine in several different species (Antia et al. 1975, Shah \& Syrett 1982, 1984).

\section{Degradation of pyrimidines}

The pyrimidines thymine, uracil and cytosine were degraded even slower than adenine. In the literature, few studies have focused on bacterial uptake and utilization of pyrimidines. According to Vogels \& van der Drift (1976) some bacteria possess reductive pathways for degradation of pyrimidines into $\mathrm{NH}_{4}{ }^{+}$and amino 
acid derivatives ( $\beta$-alanine and $\beta$-aminoisobutyric acid), but the reactions are energy-demanding and require NADPH. Alternatively, other bacteria utilize oxidative pathways in which pyrimidines are degraded to $\mathrm{NH}_{4}{ }^{+}$, urea and organic acids, but only in the absence of $\mathrm{NH}_{4}{ }^{+}$. The reason for the low consumption of pyrimidines in our experiments is not clear. Possibly, the ambient concentrations of $\mathrm{NH}_{4}{ }^{+}(3$ to $9 \mu \mathrm{M})$ and $\mathrm{NO}_{3}^{-}(30 \mu \mathrm{M})$ lowered the activity of pyrimidine degrading enzymes as observed for cytosine deaminase in Escherichia coli (Ban et al. 1972).

\section{Production of urea}

Urea production mirrored the uptake of purines and pyrimidines in that it occurred faster in the guanine, hypoxanthine and xanthine treatments, compared with the cytosine, thymine, and uracil treatments. A time lag in urea production was observed in the adenine-enriched treatments. In the $\left[{ }^{14} \mathrm{C}\right]$-adenine incubations, the production of $\left[{ }^{14} \mathrm{C}\right]$-urea peaked at $96 \mathrm{~h}$, after the bacterial density began declining (data not shown). A time lag in urea production coinciding with late exponential bacterial growth phase was also noted in Therkildsen et al. (1996) where no exogenous purine was added. In that study, production of urea was attributed to an increased degradation of intracellular RNA, occurring immediately after carbon exhaustion. This was also observed by Mason \& Egli (1993). In addition to the time lag, the efficiency of urea production was low (28 to $68 \%$ ), suggesting that adenine- $\mathrm{N}$ was used for purposes other than urea production. Urea production could be reduced by recycling adenine for the production of nucleotides or ATP (Karl \& Winn 1984), and in salvage pathways, as observed in some Archaea (Stuer-Lauridsen \& Nygaard 1998). The rate of adenine incorporation into nucleotides in marine environments is on the order of $0.025 \mathrm{nmol} \mathrm{l}^{-1} \mathrm{~h}^{-1}$ (Karl \& Bossard 1985). This is very low compared to the adenine uptake rate of $129 \mathrm{nmol}$ $\mathrm{l}^{-1} \mathrm{~h}^{-1}$ measured in the present investigation (Table 1 ), suggesting this was not a major process in our experiment. Other processes, possibly urea uptake, could have resulted in the incomplete conversion of adenine- $\mathrm{N}$ into urea-N.

Incomplete conversion of purine to urea or consumption by bacteria was evident even in the enrichments with the greatest urea production rates, xanthine and guanine, where the conversion efficiency was approximately 16 to $20 \%$ below the theoretical maximum efficiency (based on Fig. 1). Irregular decreases in urea concentrations towards the latter half of the incubation period in 5 out of 7 treatments indicated that urea was hydrolyzed to some extent by the bacteria. Nevertheless, hydrolysis rates were slow enough for urea to accumulate in all the treatments, suggesting that urea is less attractive to bacteria than nucleotide bases. Consistent with this, microcolony growth on urea-enriched seawater did not differ from growth in the control. Cho et al. (1996) found rates of bacterial urea production to be 2 orders of magnitude higher than the bacterial urea decomposition rates in coastal surface waters. These data suggest that nucleotide bases may turn over faster than urea in marine environments, and that bacteria may be net producers of urea. Studies of $\mathrm{N}$ utilization by estuarine bacteria show that uptake of urea usually is lower than uptake of free amino acids and $\mathrm{NH}_{4}{ }^{+}$, except when these components are depleted (Jørgensen 2006).

The slow utilization of urea by bacteria suggests that other trophic levels benefit from bacterial urea production. In the sea, phytoplankton uptake typically controls the community urea consumption (Tamminen \& Irmisch 1996). During summer months, when sources of dissolved inorganic $\mathrm{N}$ are scarce in many marine habitats, urea may supply upwards of $28 \%$ of the phytoplankton N demand (McCarthy 1972, Kristiansen 1983, Berg et al. 1997), and recent reports suggest that urea may be an especially important $\mathrm{N}$ source for cyanobacteria, such as Synechococcus (Berman \& Bronk 2003).

Historical data on community urea demand for the Baltic Sea region, including the Danish sea coast, allowed us to evaluate if the urea production rates observed in our experiments could contribute significantly to the community $\mathrm{N}$ demand in this region. In summer, community urea uptake rates range from 50 to $350 \mathrm{nmol}$ urea- $\mathrm{N} \mathrm{l}^{-1} \mathrm{~h}^{-1}$ (Sörenson \& Sahlsten 1987, Berg et al. 2001). Our enrichment cultures demonstrated that the estuarine bacterial populations had the potential to produce urea in this range (urea production from degradation of both adenine and guanine was $150 \mathrm{nmol}$ urea- $\mathrm{N} \mathrm{l}^{-1} \mathrm{~h}^{-1}$; Table 2). We hypothesize that the low concentrations of purines in natural waters are caused by a fast uptake and conversion to urea by bacterial assemblages. The fact that guanine and hypoxanthine were taken up more rapidly relative to adenine, the only detectable purine in seawater, suggests they cycle quicker than adenine. It should be mentioned, however, that we optimized the present approach (retention on C-18 cartridge) for detection of adenine in seawater and that modification of the technique may have allowed detection of other purines (and pyrimidines). Except for concentrations of free adenine and uracil, 0.8 to 13 and 1.8 to $6 \mu \mathrm{M}$, respectively measured in the Gulf of Mexico by a biological assay (Litchfield \& Hood 1966), we have not been able to find published data on purines or adenines in nat- 
ural waters. The concentration of adenine in Øresund (range 0.015 to $0.053 \mu \mathrm{M}$ ) is lower than the range found by Litchfield \& Hood (1966), though the 2 analytical methods may not be directly comparable. We

Table 2. Purine and pyrimidine uptake rates and urea production rates based on changes in concentration over time in Fig. 4

\begin{tabular}{|lcc|}
\hline & $\begin{array}{c}\text { Uptake rate } \\
\left(\mathrm{nmol} \mathrm{N} \mathrm{l}^{-1} \mathrm{~h}^{-1}\right)\end{array}$ & $\begin{array}{c}\text { Urea production rate } \\
\left(\mathrm{nmol} \mathrm{N}^{-1} \mathrm{~h}^{-1}\right)\end{array}$ \\
\hline Adenine & 129 & 50 \\
Guanine & 264 & 100 \\
Hypoxanthine & 210 & 130 \\
Xanthine & 207 & 90 \\
Cytosine & 24 & 20 \\
Thymine & 7 & 20 \\
Uracil & 30 & 10 \\
a Adenine uptake based on $96 \mathrm{~h}_{\text {; }}$ guanine, hypoxanthine \\
and xanthine uptake over $48 \mathrm{~h}_{\text {; }}$ cytosine, thymine and \\
uracil uptake over 141 $\mathrm{h}$ \\
bUrea production based on the first 48 h of incubation due \\
to concurrent uptake later in the time course \\
\hline
\end{tabular}
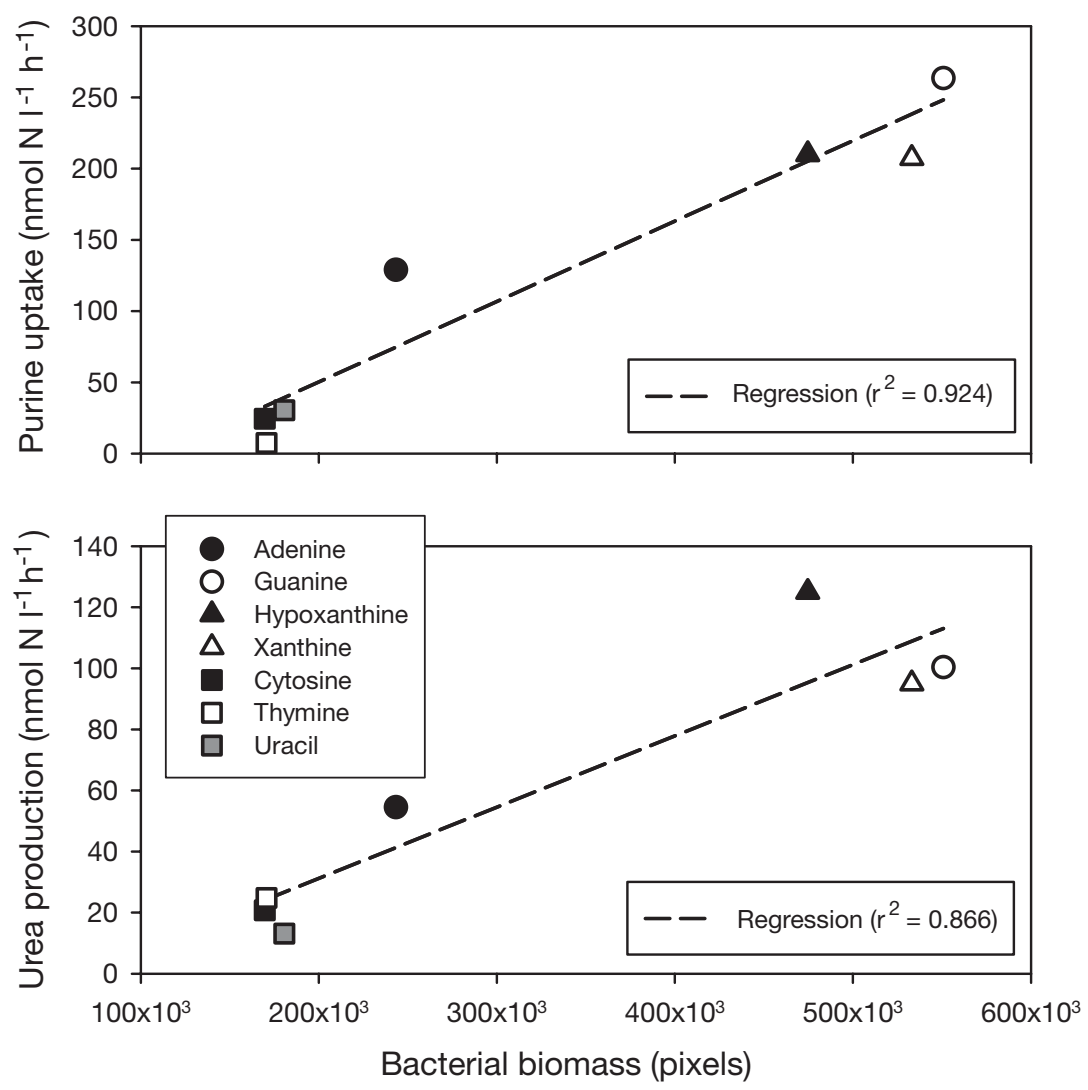

Fig. 6. (A) Purine and pyrimidine uptake as a function of total bacterial biomass in microcolonies (combination of Figs. 3A \& 5D): $y=6 \times 10^{-7} x-0.0627 ; p<0.01$.

(B) Urea production as a function of total bacterial biomass in microcolonies (combination of Figs. 3B \& 5D): $y=2 \times 10^{-7} x-0.0155 ; \mathrm{p}<0.01$ assume that the apparent low ambient concentrations of purines and pyrimidines reflect a high microbial potential for degradation of these compounds.

\section{Microcolony growth}

The formation of microcolonies on the filters floating on water enriched with urea, purines, pyrimidines and intermediates agreed well with the bacterial capacity for uptake of these compounds (Figs. $3,5 \& 6$ ). Although the number of colonies on the filters explained slightly less of the variation in substrate utilization $\left(\mathrm{r}^{2}=\right.$ $0.87)$ compared with total bacterial biomass $\left(\mathrm{r}^{2}=0.92\right.$, Fig. 6), our microcolony observations agree well with other microcolony studies in which the number of colonies was found to represent the substrate utilization (Højberg et al. 1997).

The present correlation between substrate utilization and colony density and/or biomass, may have been influenced by the relative number of microcolonies produced. Initially ca. $2 \times 10^{5}$ bacteria were added to each filter, but only 17 to 88 of these bacteria produced microcolonies, assuming that each colony originated from one bacterium. The low number of viable cells on the filters may have been caused by desiccation of the bacteria, as the filters remained uncovered when floating in the petri-dishes. To circumvent desiccation, siliconeembedding of bacteria on top of the filters has been applied in other microcolony studies (Højberg et al. 1997). Further, the small number of viable cells may have been caused slow diffusion of nutrients through the filter pores, effectively resulting in nutrient limitation of the cells. Using a more permeable filter that allows for greater diffusion of substrates may circumvent this problem. Fry \& Zia (1982) found that 10 to $20 \%$ of freshwater bacteria (based on epifluorescent microscopy counts) were able to form microcolonies on agar slides, and only when the medium was enriched with a mixture of casein, peptone and starch. This suggests that even under complete nutrient sufficiency another factor limits growth. Despite the potential limitations of the microcolony approach, the agreement between the microcolony biomass index and the uptake of purines and pyrimidines 
suggests that the microcolony formation mirrors a true metabolic potential among estuarine bacteria.

A disadvantage of the present microcolony biomass index is the time-consuming computer manipulation of the individual microcolonies, especially when the microcolony staining includes extracellular products, as in our case. The present digital manipulation of the microphotographs to remove extracellular material could also have influenced the actual cell size in some cases. Application of more DNA-specific fluorochromes than acridine orange will undoubtedly minimize the problem of interference of extracellular material.

Our observation of a grouping in bacterial cell size in microcolonies, ranging from small cells $(<100$ pixels; guanine, hypoxanthine and xanthine), intermediate cells (120 to 140 pixels; control, urea and pyrimidines), to large cells ( $>160$ pixels; adenine), on the different media may indicate that different metabolic types of bacteria were produced. The present coincidence of small cells and a fast purine metabolism may reflect that enrichment with guanine, hypoxanthine and xanthine led to selection of bacteria with a small cell size, in contrast to bacteria with a larger size growing on the other media. Molecular analysis of bacteria in the microcolonies would have allowed a more precise indication of genotypic relationships among bacteria growing on the different media.

An advantage of the microcolony technique, in addition to isolating bacteria that can grow on a specific substrate, is the ability to physically separate bacteria growing on the filters from their potential grazers. This may be the reason for the good agreement between the microcolony biomass and rates of substrate uptake, as compared to the poorer agreement between bacterial abundance in the enriched incubation flasks and substrate uptake. Nanoflagellates were observed in some treatments at $141 \mathrm{~h}$, but it cannot be excluded that grazing protists occurred earlier in some of the incubations and may have played a role in a bacterial abundance not matching the substrate depletion. As such the microcolony technique may provide an advantage when working with natural aquatic communities where separating bacteria from their grazers is desirable.

Our data demonstrate that natural marine bacterial populations have a high potential for cycling purines and their intermediates, while pyrimidines are less labile. The exception to this was the purine adenine which was intermediate in lability between purines and pyrimidines. Bacterial catabolism of purines and their intermediates appears to be an important process in the production of urea in coastal marine systems. Because coastal marine bacteria act as net producers of urea, they may serve as a source of urea- $\mathrm{N}$ for phytoplankton.
Acknowledgements. We thank R. E. Jensen for skilful technical assistance, M. Hansen for help with the image software and 2 referees for valuable comments on the manuscript. This study was supported by grants from the Danish Strategic Environmental Program II and the Danish Natural Sciences Research Council to N.O.G.J.

\section{LITERATURE CITED}

Antia NJ, Harrison PJ, Oliveira L (1991) The role of dissolved organic nitrogen in phytoplankton nutrition, cell biology and ecology. Phycologia 30:1-89

Antia NJ, Berland BR, Bonin DJ, Maestrini SY (1975) Comparative evaluation of certain organic and inorganic sources of nitrogen for phototrophic growth of marine microalgae. J Mar Biol Assoc UK 55:519-533

Ban J, Vitale L, Kos E (1972) Thymine and uracil catabolism in Escherichia coli. J Gen Microbiol 73:267-272

Berg GM, Glibert PM, Lomas MW, Burford MA (1997) Organic nitrogen uptake and growth by the chrysophyte Aureococcus anophagefferens during a brown tide event. Mar Biol 129:377-387

Berg GM, Glibert PM, Jørgensen NOG, Balode M, Purina I (2001) Variability in inorganic and organic nitrogen uptake associated with riverine nutrient input in the Gulf of Riga, Baltic Sea. Estuaries 24:204-214

Berman T, Bechemin C, Maestrini SY (1999) Release of ammonium and urea from dissolved organic nitrogen in aquatic ecosystems. Aquat Microb Ecol 16:295-302

Berman T, Bronk DA (2003) Dissolved organic nitrogen: a dynamic participant in aquatic ecosystems. Aquat Microb Ecol 31:279-305

Binnerup SJ, Jensen DF, Thordal-Christensen H, Sørensen J (1993) Detection of viable but non-culturable Pseudomonas fluorescens DF57 in soil using a microcolony epifluorescence technique. FEMS Microbiol Ecol 12:97-105

Cho BC, Park MG, Shim JH, Azam F (1996) Significance of bacteria in urea dynamics in coastal surface waters. Mar Ecol Prog Ser 142:19-26

DeMoll E, Auffenberg T (1993) Purine metabolism in Methanococcus vannielii. J Bacteriol 175:5754-5761

Eschmann K, Kaltwasser H (1980) Inhibition of purine utilization by adenine in Alcaligenes eutrophus H16. Arch Microbiol 125:29-34

Fry JC, Zia T (1982) Viability of heterotrophic bacteria in fresh-water. J Gen Microbiol 128:2841-2850

Hassan HF, Coombs GH (1988) Purine and pyrimidine metabolism in parasitic protozoa. FEMS Microbiol Rev 4:47-83

Hobbie JE, Daley RJ, Jasper S (1977) Use of nuclepore filters for counting bacteria by fluorescence microscopy. Appl Environ Microbiol 33:1225-1228

Højberg O, Binnerup SJ, Sørensen J (1997) Growth of silicone-immobilized bacteria on polycarbonate membrane filters, a technique to study microcolony formation under anaerobic conditions. Appl Environ Microbiol 63: $2920-2924$

Jørgensen NOG (2006) Uptake of urea by estuarine bacteria. Aquat Microb Ecol 42:227-242 (this issue)

Karl DM, Bossard P (1985) Measurement of microbial nucleic acid synthesis and specific growth rate by ${ }^{32} \mathrm{PO}_{4}$ and $\left[{ }^{3} \mathrm{H}\right]$ adenine: field comparison. Appl Environ Microbiol 50: 706-709

Karl DM, Winn CD (1984) Adenine metabolism and nucleic acid synthesis: applications to microbiological oceanography. In: Hobbie J, Williams P (eds) Heterotrophic activity in the sea. Plenum Press, New York, p 197-216 
Kristiansen S (1983) Urea as an important source of nitrogen in the Oslofjord. Mar Biol 74:17-24

LaRue TA, Spencer JFT (1968) The utilization of purines and pyrimidines by yeasts. Can J Microbiol 14:79-86

LeChevalier MP, Gerber NN, Umbreit TA (1982) Transformation of adenine to 8-hydroxyadenine by strains of Oerskovia xanthineolytica. Appl Environ Microbiol 43: 367-370

Litchfield CD, Hood DW (1966) Microbiological assay for organic compounds in seawater. II. Distribution of adenine uracil and threonine. Appl Microbiol 14:145-151

Mason CA, Egli T (1993) Dynamics of microbial growth in the decelerating and stationary phase of batch culture. In: Kjelleberg $\mathrm{S}$ (ed) Starvation in bacteria. Plenum Press, New York, p 81-102

McCarthy JJ (1972) The uptake of urea by natural populations of marine phytoplankton. Limnol Oceanogr 17: 738-748

Nicol JAC (1960) The biology of marine animals, 1st edn. Sir Isaac Pitman \& Sons, London

Price NM, Harrison PJ (1987) A comparison of methods for the measurement of dissolved urea concentrations in seawater. Mar Biol 92:307-319

Remsen CC (1971) The distribution of urea in coastal and oceanic waters. Limnol Oceanogr 16:732-740

Sarcina M, Casselton PJ (1995) Degradation of adenine by Prototheca zopfii (Chlorophyta). J Phycol 31:575-576

Schultz AC, Nygaard P, Saxild HH (2001) Functional analysis of genes that constitute the purine catabolic pathway in Bacillus subtilis and evidence for a novel regulon controlled by the PucR transcription activator. J Bacteriol 183: 3293-3302

Shah N, Syrett PJ (1982) Uptake of guanine by the diatom Phaeodactylum tricornutum. J Phycol 18:579-587

Editorial responsibility: Frede Thingstad, Bergen, Norway
Shah N, Syrett PJ (1984) The uptake of guanine and hypoxanthine by marine microalgae. J Mar Biol Assoc UK 64: $545-556$

Soldo AT, Godoy GA, Larin F (1978) Purine excretory nature of refractile bodies in the marine ciliate Parauronema acutum. J Protozool 25:416-418

Sörenson F, Sahlsten E (1987) Nitrogen dynamics of a cyanobacteria bloom in the Baltic Sea-new versus regenerated production. Mar Ecol Prog Ser 37:277-284

Staley KB, Ewing RD (1992) Purine levels in the skin of juvenile coho salmon (Oncorhynchus kisutch) during parrsmolt transformation and adaptation to seawater. Comp Biochem Physiol B 101B:447-452

Stuer-Lauridsen B, Nygaard P (1998) Purine salvage in two halophilic archaea: characterization of salvage pathways and isolation of mutants resistant to purine analogs. J Bacteriol 180:457-463

Tamminen T, Irmisch A (1996) Urea uptake kinetics of a midsummer planktonic community on the SW coast of Finland. Mar Ecol Prog Ser 130:201-211

Therkildsen MS, Isaksen MF, Lomstein BA (1996) Urea production by the marine bacteria Delaya venusta and Pseudomonas stutzeri grown in a minimal medium. Aquat Microb Ecol 13:213-217

Vitols M, Volsky V, Maurina H (1974) Utilization and catabolic transformation of exogenous purine and pyrimidine bases, nucleosides and nucleotides by actinomycetes. In Brownell GH (ed) Proceedings of the first international conference on biology of Nocardia. Merida, Venezuela, p 64-65

Vogels GD, van der Drift C (1976) Degradation of purines and pyrimidines by microorganisms. Bacteriol Rev 40:403-468

Watanabe Y, Ohe T (1972) Oxidation of hypoxanthine to uric acid by Streptomyces. Agric Biol Chem 36:785-792

Submitted: August 25, 2005; Accepted: November 21, 2005 Proofs received from author(s): March 9, 2006 